\title{
Formula Tepung Petul untuk Memperbaiki Status Gizi dan Kolesterol Total pada Wanita Menopause Hiperkolesterolemia
}

\author{
Sufiati Bintanah $^{1}$, Mufnaetty ${ }^{2}$ \\ 1,2 Program Studi Gizi FIKKES Universitas Muhammadiyah Semarang \\ sofi.bintanah@yahoo.com
}

\begin{abstract}
A decrease in the hormone estrogen in women can trigger changes in nutritional status and cholesterol levels that cause hypercholesterolemia, so that antioxidant compounds and fiber are needed to improve one of them is in tempeh flour and rice bran. This study aims to prove the effect of giving a combination of tempeh flour and bran (Petul) on nutritional status and total cholesterol levels in menopausal women with hypercholesterolemia. Methods: Randomized control group pretestposttest control group design, carried out on 60 menopausal women at least 1 year with hypercholesterolemia, not taking medication who were divided into intervention groups (given a formula $37.33 \mathrm{~g} /$ drink 3 times a day for 3 weeks) and placebo in the control group. The variables studied before and after the intervention were nutritional status and total cholesterol levels. Independent statistical analysis of t test, dependent t test and Ringspearmen correlation test. Results: Combination of PETUL as much as $37.33 \mathrm{~g} /$ drink 3 times / day for 3 weeks can improve nutritional status but has no significant and significant effect on reducing total cholesterol levels. Consclusion : PETUL formula can improve nutritional status and reduce total cholesterol levels.
\end{abstract}

Keywords: Formula, Petul, nutritional status, menopausal women, hypercholesterolemia

\section{PENDAHULUAN}

Hiperkolesterol merupakan salah satu gangguan lemak darah yang ditandai dengan kadar kolesterol total dalam darah melebihi batas norma (Hirano et al., 2004), dan merupakan salah satu penyebab penyakit kardiovaskular akibat asupan makanan yang rendah serat tetapi tinggi lemak dan dengan gaya hidup yang tidak sehat seperti merokok, kurang berolahraga dan lain - lain (Utaminingsih, 2009). World Health Organization (WHO) melaporkan bahwa pada tahun 2002 terdapat 4,4 juta $(7,7 \%)$ dari total kematian akibat hiperkolesterolemia . Hasil penelitian Framingham menunjukkan bahwa apabila kadar kolesterol darah meningkat dari Jurnal Gizi Unimus Vol 10 No 12021
$150 \mathrm{mg} / \mathrm{dl}$ menjadi $260 \mathrm{mg} / \mathrm{dl}$, maka akan meningkatkan resiko penyakit jantung menjadi tiga kali lipat.(World Health Organization, 2008). Berdasarkan data National Center Haealth Statistic (NCHS) pada tahun 20092010 menunjukkan $12,2 \%$ pada laki-laki dan $14,3 \%$ pada perempuan dengan usia $>20$ tahun memiliki kadar kolestrol total $\geq 200$ mg/dl.(Carrol et al,2012). Data Survei Kesehatan Rumah Tangga (SKRT) dalam Balitbangkes (2004), menunjukkan bahwa prevalensi hiperkolesterolemia di Indonesia padausia $\geq 25$ tahuna $13,6 \%$ laki-laki $9,2 \%$ danwanita $16,7 \%$. Menurut Riskesdas tahun 2013 prevalensi hiperkolesterolemia berdasarkan jenis kelamin dan tempat tinggal 
didapatkan pada laki-laki 30,0 \% dan pada perempuan lebih tinggi sebesar 39,6\%. Menurut Sihadi (2006), perempuan lebih berisiko terjadinya hiperlipidemia disebabkan karena faktor hormonal, kehamilan, dan menopause. Penurunan hormon esterogen pada wanita karena terjadi penurunan fungsi ovarium sehingga tidak mengalami menstruasi yang disebut menopause.(Borden L, 2013) Organisasi kesehatan dunia World Health Organization (WHO) tahun 2010 mencatat sebanyak 894 juta wanita mengalami menopause, dan diperkirakan tahun 2030 akan meningkat menjadi 1,2 milyar orang. Wanita di Indonesia yang telah memasuki usia menopause sebanyak 27,71 juta tahun 2019 dan tahun 2025 diperkirakan meningkat menjadi 60 juta. Meningkatnya populasi wanita berusia lebih dari 50 tahun menunjukkan bahwa semakin banyak wanita yang akan melewati fase menopause sehingga perlu dipikirkan untuk bisa melalui kehidupan yang berkualitas.(Badan pusat statistic, 2010)

Kadar kolesterol total pada wanita di dalam darah meningkat seiring bertambahnya usia terutama pada usia 40 tahun keatas yang disebabkan karena semakin menurunnya fungsi dan produksi kadar hormon estrogen.( Labarthe, D.R. 2011) Penurunan produksi estrogen pada wanita menopause dapat menyebabkan gangguan metabolisme lipid darah dan peningkatan berat badan yang disebabkan karena menurunnya aktifitas karena perubahan distribusi lemak tubuh, termasuk Jurnal Gizi Unimus Vol 10 No 12021 peningkatan total massa lemak dan obesitas sentral yang ditandai dengan Indeks Massa Tubuh (IMT) lebih dari $25 \mathrm{~kg} / \mathrm{m} 2$. (Yi KW et.all, 2008)

Salah satu upaya untuk memperbaiki hiperkolesterol darah melalui farmakologis, non-farmakologis, dan gabungan farmakologi dan non-farmakologis untuk mencapai kadar kolesterol total bawah $200 \mathrm{mg} / \mathrm{dl}$. (Erwanto, et al., 2013).

Upaya non-farmakologis untuk mencegah dan memperbaiki profil lipid dengan mengontrol berat badan, diet rendah kolesterol, olahraga teratur, dan konsumsi bahan makanan yang mengandung antioksidan dari vitamin A,E dan $\mathrm{C}$ dan serat yang mampu menurunkan kadar kolesterol darah. Hasil penelitian menunjukkan bahwa vitamin $\mathrm{E}$ memiliki efek terbaik untuk stres oksidative akibat hiperkolesterol dan obesitas dibandingkan vitamin $\mathrm{A}$ dan $\mathrm{C}$ serta kandungan serat pangan yang tinggi untuk mengurangi peroksidasi lipid ( Zaidi, 2004) Salah satu sumber vitamin E berupa tokoferol dan serat pangan yang terdapat pada bekatul. Selain vitamin E antioksidan dari kelompok flavonoid (1,2diarylpropane) juga berpotensi untuk mengurangi kadar kolesterol darah melalui katabolisme sel lemak sebagai sumber energi, yang meningkatkan pembersihan kolesterol dari aliran darah sehingga terjadi penurunan kadar kolesterol didalam darah (Clairr, et al, 2008). Sumber isoflavon salah satunya terdapat pada kedelai. 
Kedelai mengandung antioksidan berupa isoflavon (genistein dan daidzein) merupakan suatu fitoestrogen yang dapat berikatan dengan reseptor endogen dan bersifat kardioprotektif karena bertindak menyerupai estrogen sebagai antioksidan yang menetralisir radikal bebas dengan cara memberikan efek terhadap peningkatan aktivitas up regulating reseptor kolestarol LDL kemudian akan meningkatkan kolesterol LDL clearances dari peredaran darah dan mengurangi kadar kolesterol LDL dalam darah (Ilsakova,et al, 2010; Cena ER, et al. 2011).

Produk dari kedelelai adalah tempe kedelai. Salah satu alternatif untuk memperpanjang masa simpan tempe adalah dengan cara dibuat tepung tempe.(Nout MJR. 2005; Susi A, 2008). Kandungan isoflavon pada tepung tempe kedelai lebih tinggi dibandingkan dengan tempe maupun tepung kedelai. (Astuti, 2000). Aktifitas biologis tempe meningkat dibanding kedelai yaitu meningkatkat isoflavon sebesar $222,5 \%$ dan menurunkan asam fitat sebesar $65 \%$ akibat reaksi enzim fitat yang diproduksi oleh Rhizopus oligosporus serta meningkatkan serat pangan. (Astuti, 2000; Susi A. 2008).

Tepung tempe dan bekatul (Petul) apabila dikombinasikan akan menghasilkan antiokasidan yang saling melengkapi serta meningkatkan jumlah serat pangan untuk memperbaiki status profil lipid pada wanita menopause dengan dyslipidemia.

\section{METODE PENELITIAN}

Jurnal Gizi Unimus Vol 10 No 12021
Desain Penelitian true eksperimental dengan randomized controlled group pretestpostest control group design. Populasi Penelitian adalah wanita menopause minimal 1 tahun. yang menjadi binaan posyandu lansia di Kecamatan Temanggung . Subjek Penelitian wanita menopause yang terdaftar di posyandu lansia Kecamatan Temanggung, mengalami dislipidemia, tidak mempunyai riwayat atau sedang mengalami penyakit hati, ginjal, gangguan tiroid, kanker, PJK, stroke, diabetes mellitus, tidak mengkonsumsi suplemen, tidak mengkonsumsi obat hipoglikemi, fitofarmaka, hipolipidemia., penganut vegetarian dan menggunakan terapi estrogen serta bersedia untuk mengukuti proses anamnesis, pemeriksaan fisik, antropometri, dan penapisan pemeriksaan darah. Jumlah sampel sebanyak 60 wanita menopause dengan dislipidemia yang diambil dengan cara consecutive sampling. Sebanyak 60 sampel kemudian dilakukan randomisasi untuk menentukan subjek masuk dalam kelompok kontrol dan kelompok intervensi.Penentuan status gizi dilakukan dengan menimbang BB menggunakan timbangan dacin digital sedangkan pengukuran tinggi badan menggunakan microtoice. Pembuatan formula Petul dilakukan di laboratorium Teknologi Pangan Unimus. Bahan pembuat formula petul intervensi terdiri dari tepung tempe kedelai dan bekatul dengan perbandingan 1:1 dan pemanis 
non kalori. Cara membuat formula adalah : campur semua bahan kedalam mixer, kemudian di blander untuk mendapatkan hasil yang optimum, dianalisa kadar Air, protein, lemak, karbohidrat, serat, vitamin E dan kadar isoflavon. Penyajian perporsi adalah satu bungkus diencerkan dengan air dingin/hangat sebanyak 200 cc. Dalam satu hari diberikan 3 bungkus selama 21 hari. Kadar kolesterol diambil sebelum perlakuan dan sesudah 3 minggu perlakuan. Pengambilan darah dilakukan dipagi hari jam 08.00 sesudah puasa 12 jam melalui darah vena. Darah yang diambil dimasukkan ke dalam tabung vacum. Sesudah terkumpul kemudian dimasukkan kedalam cold box yang dilengkapi dengan thermometer dengan suhu 2-8 ${ }^{\circ} \mathrm{C}$ untuk diperiksa di laboratorium.

Data konsumsi pangan (food record, food recall dan FFQ) direkapitulasi untuk mengetahui berbagai jenis pangan dan ukuran (gram) yang dikonsumsi subjek ke dalam soft ware Nutrisurvey untuk dihitung energi, karbohidrat, protein, lemak, kolesterol, serat, vitamin E,vitamin $\mathrm{C}$, vitamin $\mathrm{A}$ isoflavon, $\mathrm{Zn}$ Hasil tersebut kemudian dibandingkan dengan AKG (WKNPG 2013).

Analisa data menggunakan soft ware statistic. Uji kenormalan menggunakan kolmogorov smirnof dan untuk mengetahui perbedaan antara sebelum dan sesudah perlakuan dianalisis menggunakan independen t- test untuk data yang berdistribusi nornal, untuk melihat perbedaan variabel sebelum dan Jurnal Gizi Unimus Vol 10 No 12021 sesudah perlakuan pada kelompok intervensi dan kontrol mengunakan paired t- test. Untuk data kategorik dianalisis menggunakan uji Chi Square.

\section{HASIL DAN PEMBAHASAN}

\section{Status Gizi Subjek}

Tabel.1. Distribusi status gizi subjek berdasarkan IMT sebelum perlakuan

\begin{tabular}{lccccc}
\hline Kelompok & \multicolumn{3}{c}{ IMT $(\mathrm{Kg} / \mathrm{m} 2)$} & $\mathrm{t}$ & $\mathrm{P}$ \\
\cline { 2 - 4 } & $\min$ & Mak & Mean \pm SD & & \\
\hline Intervensi & 20.55 & 36.58 & $27.21 \pm 3.19$ & 0.436 & $0.664^{* *}$ \\
Kontrol & 23.31 & 36.71 & $27.56 \pm 2.91$ & & \\
\hline \multicolumn{1}{c}{ Keterangan : ** Independen $t$ test $(\mathrm{p}>0.05)$ tidak berbeda nyata }
\end{tabular}

Rerata status gizi berdasarka IMT pada tabel 1 baik pada subjek kelompok intervensi dan kontrol sebelum perlakuan sebesar $27,21 \pm 3,19 \mathrm{~kg} / \mathrm{m} 2$ dan $27,56 \pm 2,91 \mathrm{~kg} / \mathrm{m} 2$. Hasil analisis menunjukkan kedua kelompok tidak terdapat perbedaan $(\mathrm{p}=0,664>0.05)$.

Banyak teori menyatakan bahwa bagi seorang wanita, risiko terjadinya kelebihan berat badan (kegemukan) semakin meningkat dengan semakin bertambahnya usia. Hal tersebut terbukti pada gambar 1 bahwa sebelum perlakuan hanya satu subjek dalam penelitian yang memiliki IMT normal .

Rerata IMT pada kelompok control dan intervensi sebelum perlakuan terdapat $16.65 \%$ terkategori overweight dan $81.7 \%$ terkategori obesitas diantaranya 70,05\% obesiatas tingkat I dan $11,65 \%$ obesitas tingkat II. Sesudah perlakuan pada kelompok intervensi terjadi peningkatan untuk kategori normal menjadi $6,66 \%$, sedangkan untuk yang tidak normal terjadi peningkatan 
sebesar $6,67 \%$ menjadi $26,67 \%$ pada kategori overweight sedangkan pada kateori obesitas TK.1 terjadi penurunan sebesar 10,03\% (Gambar2)

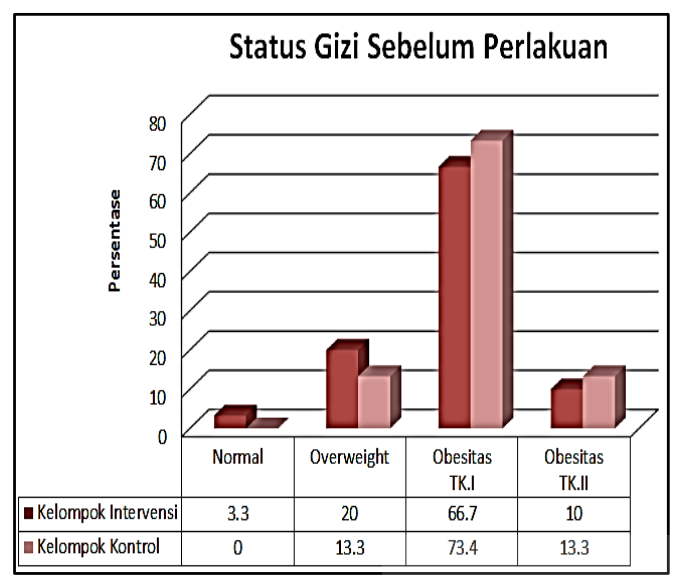

Gambar. 1.Distribusi status gizi berdasarkan IMT sebelum perlakuan

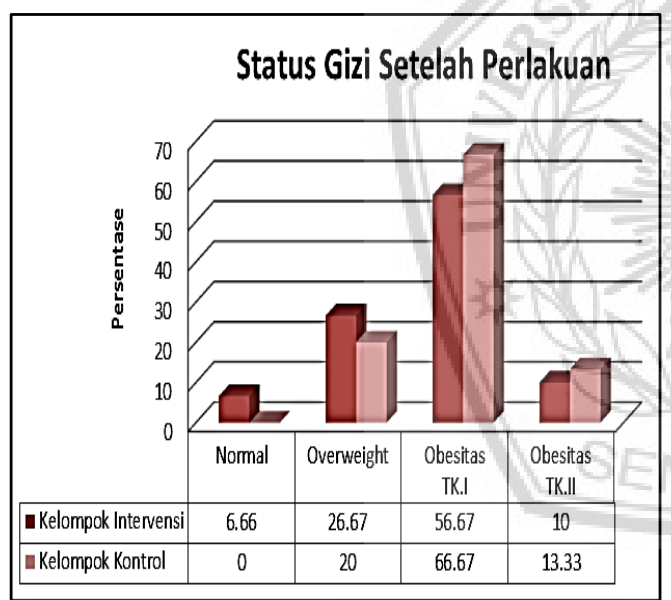

Gambar.2. Distribusi status gizi berdasarkan IMT setelah perlakuan.

Tabel. 2. Pengaruh petul terhadap status gizi subjek berdasarkan IMT

\begin{tabular}{|c|c|c|c|c|c|}
\hline \multirow[t]{2}{*}{ Kelompok } & \multicolumn{3}{|c|}{ Status Gizi (IMT) } & \multirow[t]{2}{*}{$\mathrm{t}$} & \multirow[t]{2}{*}{$\mathrm{P}$} \\
\hline & $\min$ & Maks & $\begin{array}{c}\text { Mean } \\
\pm \text { SD }\end{array}$ & & \\
\hline Intervensi & 20.29 & 36.09 & $26.64 \pm 3.17$ & 1,039 & $0.303 * *$ \\
\hline Kontrol & 23.31 & $36 / 00$ & $27.45 \pm 4.17$ & & \\
\hline
\end{tabular}

Rerata status gizi berdasarkan IMT setelah perlakuan pada table 2 baik pada kelompok intervensi maupun kontrol terjadi penurunan. Rerata IMT subjek kelompok intervensi setelah perlakuan terjadi penurunan dari $27.21 \pm 3.19$ menjadi $26,64 \pm 3,17 . \mathrm{kg} / \mathrm{m} 2$ dan pada kelompok control dari 27.56 \pm 2.91 menjadi $27.45 \pm 4,17 . \mathrm{kg} / \mathrm{m} 2$. Penurunan IMT pada kelompok intervensi lebih banyak dibandingkan pada kelompok kontrol.

Hasil uji beda rerata antar kelompok perlakuan pada subjek intervensi dan kontrol sebelum intervensi diperoleh nilai $\mathrm{p}=0.664>$ 0.05 , dan setelah intervensi $\mathrm{p}=0.303>0.05$ artinya bahwa status gizi subjek sebelum dan setelah perlakuan tidak berbeda antara kelompok intervensi dan kontrol, namun gambar 1 dan 2 menunjukkan kedua kelompok lebih dari 50\% masih memiliki status gizi lebih dengan persentase tertinggi pada kelompok kontrol sebesar $66.6 \%$.

Hasil penelitian ini sejalan dengan penelitian/terdahulu yang menunjukkan bahwa. Hampir dua per tiga wanita menopause $(68,0 \%)$ memiliki IMT tidak normal yang terbagi menjadi $20,8 \%$ overweight dan $47,2 \%$ obesitas baik obesitas TK I maupun obesitas TK II berdasarkan WHO (2000).( Utari,D.M. 2011).

Penyebab obesitas adalah multifaktor, antara lain interaksi antara latar belakang genetik, hormon, faktor sosial dan lingkungan seperti gaya hidup dan kebiasaan makan yang kurang baik serta kurangnya aktivitas fisik ( Charles. R, et al. 2012) Status gizi menggambarkan apa yang dikonsumsinya dalam waktu yang cukup lama, dan merupakan akibat dari keseimbangan antara konsumsi 
dengan penyerapan zat gizi serta penggunaan zat-zat gizi tersebut secara fisiologis akibat tersedianya zat gizi dalam seluler tubuh. Pola makan yang tidak seimbang antara asupan dengan kebutuhan baik jumlah maupun jenis makanannnya dapat menyebabkan kegemukan atau obesitas.(Zakaria FR, et al. 2000). Riskesdas 2013 menunjukan bahwa adanya peningkatan obesitas pada lansia (usia 56-65 tahun), tahun 2007 sebesar 14,8\% dengan IMT $>25,0$ dan meningkat menjadi $32,9 \%$ pada tahun 2013.( Riskesdas, 2013).

\section{Pola Makan Subjek}

Pada penelitian ini dilakukan recall sebanyak dua kali dalam satu minggu selama tiga minggu . Asupan yang diperoleh kemudian dibandingkan dengan angka kecukupan gizi yang dianjurkan (AKG tahun 2013) untuk mengetahui tingkat pemenuhan asupan (\%) zat gizi subjek dan dapat dilihat pada tabel 1 .

Tingkat asupan zat gizi (energi, protein, lemak, karbohidrat, vitamin A, vitamin $\mathrm{C}$, vitamin $\mathrm{E}$ serat, isoflavon) antara kelompok intervensi dan kontrol dalam jumlah yang tidak berbeda p-value $>0,005$. Rerata tingkat asupan energi, protein, karbohidrat, vitamin C, vitamin E dan serat pada kelompok intervensi sedikit lebih tinggi dibandingkan kelompok kontrol, namun untuk tingkat asupan lemak, vitamin A dan isoflavon pada kelompok kontrol sedikit lebih tinggi dibandingkan kelompok intervensi. Rerata tingkat asupan energi dan karbohidrat mencapai > 100\% AKG pada kedua kelompok sedangkan rerata tingkat asupan vitamin $\mathrm{A}$, vinamin $\mathrm{C}$ vitamin $\mathrm{E}$, serat, dan isovlavon masih dibawah 50\% dari AKG.

Tabel 3. Rerata Asupan Zat Gizi Subjek

\begin{tabular}{|c|c|c|c|}
\hline \multirow[b]{2}{*}{ Variabel } & \multicolumn{2}{|c|}{ Rerata \pm SD } & \multirow[b]{2}{*}{$\mathrm{p}$} \\
\hline & $\begin{array}{c}\text { Intervensi } \\
n=30\end{array}$ & $\begin{array}{c}\text { Kontrol } \\
n=30\end{array}$ & \\
\hline $\begin{array}{l}\text { Energi }(\%), \\
(\text { rerata } \pm \mathrm{SB} ; \min -\max )\end{array}$ & $\begin{array}{r}105,9 \pm 13,8 \\
85,0-134,0\end{array}$ & $\begin{array}{r}102,6 \pm 15,3 ; \\
68,0 ; 136,0\end{array}$ & $0,384^{\mathrm{b}}$ \\
\hline $\begin{array}{l}\text { Protein }(\%) \\
(\text { rerata } \pm \mathrm{SB} ; \min -\max )\end{array}$ & $\begin{array}{r}88,9 \pm 12,2 \\
72,0-116,0\end{array}$ & $\begin{array}{r}85,9 \pm 8,8 \\
72,0-103,0\end{array}$ & $0,296^{\mathrm{b}}$ \\
\hline $\begin{array}{l}\text { Lemak }(\%) \\
(\text { rerata } \pm \text { SB } ; \min -m a x)\end{array}$ & $\begin{array}{r}94,3 \pm 12,8 \\
73,0-129,0\end{array}$ & $\begin{array}{l}94,9 \pm 18,7 \\
54,0-150,0\end{array}$ & $0,873^{\mathrm{b}}$ \\
\hline $\begin{array}{l}\mathrm{KH}(\%) \\
(\text { rerata } \pm \mathrm{SB} ; \min -\max )\end{array}$ & $\begin{array}{r}118,8 \pm 17,9 \\
88,0-159,0\end{array}$ & $\begin{array}{r}117,5 \pm 20,6 \\
88,0-168,0\end{array}$ & $0,795^{\mathrm{b}}$ \\
\hline $\begin{array}{l}\text { Vit A }(\% .) \\
(\text { rerata } \pm \text { SB ;min-max })\end{array}$ & $\begin{array}{r}46,7 \pm 22,9 ; \\
2,0-91,0\end{array}$ & $\begin{array}{r}56,2 \pm 27 \\
8 ; 4,0-116,0\end{array}$ & $0,184^{\mathrm{a}}$ \\
\hline $\begin{array}{l}\text { Vit. C }(\%), \\
(\text { rerata } \pm \text { SB ;min-max })\end{array}$ & $\begin{array}{r}52,7 \pm 35,0 \\
2,0-130,0\end{array}$ & $\begin{array}{l}46,6 \pm 32,0 \\
10,0-110,0\end{array}$ & $0,482^{\mathrm{a}}$ \\
\hline $\begin{array}{l}\text { Vit. } \mathrm{E}(\%) \\
\text {,(rerata } \pm \mathrm{SB} ; \min -\max )\end{array}$ & $\begin{array}{r}9,6 \pm 5,2 \\
2,0-20,0\end{array}$ & $\begin{array}{r}8,6 \pm 4,9-20,0 \\
1,0-20,0\end{array}$ & $0,464^{\mathrm{a}}$ \\
\hline Isoflavon $(\%)$ & $53,7 \pm 309$ & $56,3 \pm 19,7$ & \\
\hline$($ rerata $\pm \mathrm{SB} ;$ min-max $)$ & $14,0-139,0$ & $21,0-96,0$ & $0,688^{\circ}$ \\
\hline $\begin{array}{l}\text { Serat }(\%) \\
(\text { rerata } \pm \mathrm{SB} ; \min -\max )\end{array}$ & $\begin{array}{r}30,8 \pm 8,4 ; \\
15,0-48,0\end{array}$ & $\begin{array}{r}29,5 \pm 7,1 ; \\
14,0-43,0\end{array}$ & $0,534^{\mathrm{a}}$ \\
\hline
\end{tabular}

Hasil penelitian menunjukkan bahwa rerata asupan energi kelompok intervensi selama perlakuan sebesar $105,86 \%$ dari kebutuhan dan pada kelompok kontrol dengan rerata sebesar $102,56 \%$ dari kebutuhan. Asupan total energi termasuk dalam kategori cukup adalah antara 80-100\% berdasarkan AKG. Apabila jumlah energi yang masuk lebih besar dari energi yang digunakan akan berdampak pada peningkatan berat badan.

Hasil penelitian ini juga menunjukkan bahwa asupan karbohidrat kedua kelompok melebihi kebutuhan. Berdasarkan Pedoman Umum Gizi Seimbang (PUGS) disebutkan bahwa kebutuhan karbohidrat dengan proporsi sebesar 50\%-60\% dari total energi bagi wanita diatas 50 tahun. Data dari Survei Konsumsi 
Makan Indonesia (SKMI) menunjukkan bahwa rerata asupan karbohidrat di Indonesia adalah 60\%-70\% dari total kalori.(Depkes RI, 2006) Asupan karbohidrat berlebih disebabkan karena subjek mengkonsumsi makan dengan frekuensi 4x/hari selain makan pagi, siang dan sore dengan makanan pokok sebagai sumber karbohidrat nasi, malam hari makan sumber karbohidrat berupa mie rebus, mie goreng atau nasi goreng, sedangkan subjek yang frekuensi makan 1x/hari hanya mengonsumsi makanan pokok sebagai sumber karbohidrat berupa nasi pada siang hari, untuk pagi dan sore hari menggantinya dengan sumber karbohidrat berupa singkong, ubi , talas, jagung dimasak dengan di kukus, direbus atau berupa produk makanan, dan subjek yang makanan $2 \mathrm{x} / \mathrm{hr}$ pada umumnya makan pada menjelang siang dan sore hari, di pagi hari hanya mengonsumsi sumber karbohidrat berupa roti atau gorengan (singkong goreng, tempe kemul, tahu goreng) dan minum teh atau kopi dengan menggunakan gula pasir 1 takar (20gram). Asupan karbohidrat yang tinggi berdampak pada peningkatan kadar trigliserida.(Groper SS, et al, 2005) Jenis karohidrat yang dikonsumsi subjek sebagian besar adalah berjenis refined yaitu karbohidrat yang telah mengalami pengolahan sehingga telah mengalami perubahan struktur dan kandungan mikronutrien dan pengurangan kandungan serat, beberapa jenis makanan yang dikonsumsi juga ditambahkan gula atau garam dalam pengolahannya. Karbohidrat refined memiliki molekul yang lebih kecil sehingga Jurnal Gizi Unimus Vol 10 No 12021 lebih cepat mengalami proses absorbsi di usus, lebih cepat dimetabolisme oleh enzim-enzim digestif, dan lebih mudah terjadi lonjakan kadar glukosa dalam plasma. Hasil penelitian lain menunjukkan adanya hubungan positif yang signifikan antara asupan karbohidrat dengan kadar trigliserid.(Sugiri, 2013) . Asupan karbohidrat yang berlebihan akan menyebabkan peningkatan gula darah dan juga peningkatan insulin. Insulin bekerja dengan cara memindahkan gula darah ke dalam sel untuk diubah menjadi energi dan glikogen. Apabila sel tersebut sudah penuh dengan glikogen, maka kelebihan gula darah akan diubah menjadi acetyl-CoA, lalu diubah kembali menjadi malonyl-CoA. Malonyl-CoA yang sudah terbentuk akan diubah kembali menjadi asam lemak bebas yang nantinya akan disimpan dalam bentuk trigliserida. Peningkatan asupan karbohidrat juga akan meningkatkan kadar trigliserida dalam darah. (Groper SS, et al. 2005)

\section{Pengaruh Pemberian Formula PETUL Terhadap Profil Lipid Kadar K-Total, Wanita Menopause Dislipidemia}

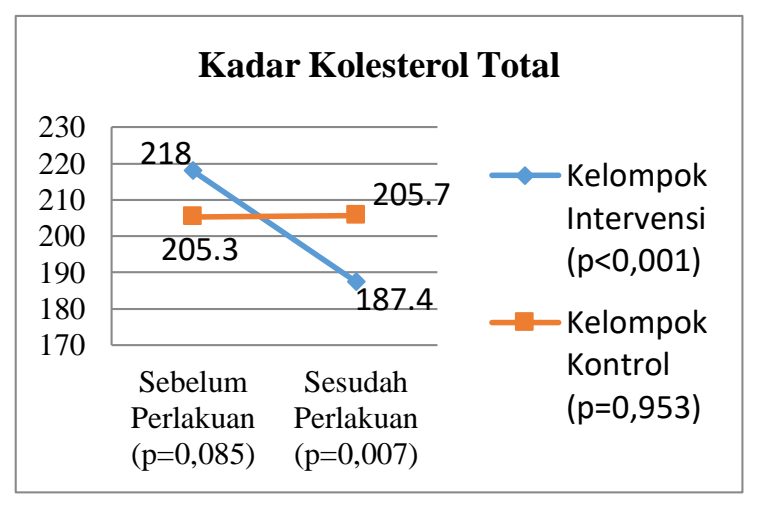

Gambar 3. Pengaruh Formula Petul terhadap kadar kolesterol total pada wanita menopause 
dislipidemia

Hasil analisis pengaruh formula Petul terhadap kadar kolesterol total yang ditunjukkan pada gambar 3 pada kelompok intervensi dan kontrol sebelum perlakuan memiliki kadar yang tidak berbeda p-value $=0,085$ dengan kadar diatas normal $(>200$ $\mathrm{mg} / \mathrm{dl}$ ) dan setelah pemberian formula Petulpada kelompok intervensi terjadi penurunan sebesar $14,03 \%$ dari kadar awal sedangkan pada kelompok kontrol terjadi sedikit kenaikan dan perubahan tersebut signifikan p-value $=0,007$. Apabila dibandingkan perubahan antara sebelum dan sesudah perlakuan pada kelompok intervensi signifikan $\mathrm{p}<0,001$ menurun sedangkan pada kelompok kontror tidak signifikan $\mathrm{p}=0,953$.

Hasil penelitian ditunjukkan pada gambar 3 bahwa wanita menopause yang diberi intervensi Petulsebanyak 37,33 g dengan frekuensi $3 x$ sehari ( $112 \mathrm{~g} / \mathrm{hr}$ ) selama 3 minggu dapat menurunkan kadar kolesterol total sebesar 30,6 mg/dl (14\%)

Hasi penelitian ini sejalalan dengan penelitian yang dilakukan Anderson, 2005 dengan meta analisis yang mereview 23 penelitian klinis yang dipublikasi tahun 1995 hingga tahun 2000 mengatakan bahwa isoflavon pada tempe secara signifikan menurunkan kolesterol total sebesar $3,77 \%$, (Anderson JW, et al. 2005) Hasil penelitian lain dengan memberikan bekatul dalam bentuk minuman pada penderita hiperkolesterol sebanyak 100 g/hari selama 3 minggu dapat menurunkan kolesterol total sebesar 7,0\%. (Hesgsted M, et al 2003) Selain isoflavon yang terdapat dalam kedelai sebagai zat antioksidan dan zat hipolipidemik, juga terdapat $\alpha$ tocopherol yang terdapat pada bekatul. Bekatul memiliki kandungan gizi yang cukup tinggi dan komponen bioaktif $\alpha$-tocopherol, menjadikan bekatul sebagai bahan baku yang berpotensi untuk dijadikan pangan fungsional. Bekatul tersusun atas protein, lemak, vitamin, mineral dan serat.(Sharif, et al. 2014)

Komponen bekatul yang dapat menurunkan kolesterol total adalah $\alpha$ tocopherol dan serat pangan larut. Mekanisme kerja $\alpha$-tocopherol dalam menurunkan kadar kolesterol dengan cara menekan peroksidasi lipid melalui penangkapan radikal bebas termasuk dalam peroksidasi atau melalui reaksi dengan radikal peroksil lipid. $\alpha$-tocopherol merupakan antioksidan pemecah rantai radikal bebas yang kuat dan paling potensial.(Luh BS, et al. 2000) Daya kerja $\alpha$-tocopherol pada hiperkolesterolemia adalah menghambat proteinkinase C-a (PKC-a) yang terlibat dalam jalur transduksi sinyal proliferatif. Aktivasi PKC diketahui menyebabkan peningkatan aktivitas transkripsi Activator protein 1(AP-1); Dengan demikian, penghambatan PKC oleh $\alpha$ tocopherol menyebabkan perubahan pola ekspresi gen pada aterosklerosis. Perubahan tersebut dengan cara reseptor yang mengambil lipoprotein, yang mengarah ke pembentukan sel busa pada lesi aterogenik sehingga tidak 
terjadi pembentukan pada sel busa tersebut. Reseptor ini termasuk SR-A, SR-B1, CD36, CD68, dan LOX-1.5..(Ricciarelli.et al, 2000). Kandungan serat pangan (dietary fiber) berguna sebagai zat hipokolesterolemik atau dapat menurunkan kadar kolesterol darah karena dapat mengikat asam empedu di dalam saluran pencernaan sehingga menurunkan penyerapan kembali asam empedu oleh dinding usus halus kemudian terbuang bersama feses sehingga jumlah asam empedu yang terserap berkurang dan meningkatkan pembentukan asam empedu baru dari kolesterol. Pengikatan asam empedu menyebabkan penyerapan lemak dalam usus menurun.( Van Bennekum AM, et al. 2005). Hasil penelitian menunjukkan bahwa tikus hiperlipidemia yang diberi $\alpha$-tocopherol menunjukkan berkurangnya kejadian aterosklerosis. (Wilson RB, et al. 2008)' Tempe kedelai dan bekatul mengandung serat yang cukup tinggi. Sesudah fermentasi, serat dalam tempe meningkat hingga tujuh kali lipat dibanding kedelai yang disebabkan karena adanya pertumbuhan miselium Rhizopus. Dalam serat juga terkandung saponin yang mampu menghambat penyerapan kolesterol sehingga dapat mendukung penurunan kadar kolesterol.( Astuti, 2012)

Sesudah perlakuan kadar kolesterol total kelompok kontrol masih diatas normal. Hal tersebut diduga disebabkan karena kelompok kontrol tidak diberikan formula yang mengandung isoflavon dan a-tocopherol. Tingginya kadar kolesterol selain disebabkan Jurnal Gizi Unimus Vol 10 No 12021 karena subjek pada kelompok kontrol tidak diberi formula, juga berkaitan dengan asupan makan dari sumber karbohidrat yang melebihi kebutuhan, serta asupan serat, vitamin A,vitamin $\mathrm{C}$, vitamin $\mathrm{E}$ dan isovlavon yang masih kurang dari kebutuhan serta status gizi yang masih diatas normal yaitu dengan kategori overweight dan obesitas baik tingkat I maupun tingkat II

Penurunan estrogen endogen, asupan makan yang tinggi kalori (protein, lemak dan karbohidrat ), rendah serat dan aktifitas fisik yang kurang berkorelasi dengan munculnya perubahan distribusi lemak tubuh, termasuk peningkatan total massa lemak dan obesitas sentral yang memicu terbentuknya sitokin pro inflamasi TNF- $\alpha$, NFK- $\beta$, IL-1 $\beta$, IL-6 sehingga timbul stres oksidatif karena ketidak seimbangan prooksidan dan antioksidan di dalam tubuh serta meningkatkan pembentukan Reactive oxygen species (ROS). Proses lipolisis pada obesitas menyebabkan pelepasan asam lemak yang berlebihan. Pelepasan asam lemak dari deposit jaringan adiposa juga menghambat lipogenesis dan terjadi proses lipotoksisitas. Lipotoksisitas dari asam lemak menurunkan sekresi insulin sehingga menimbulkan resistensi isulin yang menyebabkan penurunan efisiensi insulin dalam inhibisi lipolisis trigliserida oleh hormone-sensitive lipase (HSL) sehingga terjadi peningkatan asam lemak bebas ke dalam hati dan berkontribusi dalam penimbunan lemak di hati. Resistensi insulin juga 
menyebabkan gangguan aktivasi lipoprotein lipase (LPL) yang menyebabkan terjadi peningkatan kadar trigliserida di sirkulasi darah.

Peningkatan kadar trigliserida ini diimbangi dengan meningkatnya katabolisme dari HDL. Semakin rendah HDL, maka semakin banyak kolesterol yang yang tidak terangkut kembali ke hati, dan semakin tinggi pula risiko terjadinya aterosklerosis.(Gruber, et al. 2002) HDL (Hight Density Lipoprotein) berfungsi untuk membawa kolesterol bebas dari jaringan perifer menuju hati. Kolesterol ini diubah menjadi kolesterol ester yang sebagian dipindahkan ke VLDL melalui bantuan enzim CETP dan dikembalikan lagi ke hati oleh IDL dan LDL. Hati akan memanfaatkan kembali kolesterol ini untuk diubah menjadi garam empedu. Penelitian lain membuktikan bahwa diet tinggi karbohidrat dapat menyebabkan penurunan kadar kolesterol HDL lewat penghambatan kerja enzim lesitin kolesterol asiltransferase (LCAT) dan penurunan apolipoprotein A-1. Apolipoprotein A-1 sebagai salah satu komponen utama dari HDL berfungsi menurunkan pembentukan LDL teroksidasi, sehingga semakin tinggi kolesterol HDL, akan semakin tinggi pula proteksi terhadap terjadinya oksidasi kolesterol LDL.( Taku K, et al. 2007)

Beberapa penelitian lain menunjukkan hubungan antara asupan karbohidrat dengan kadar cholesterol total yang berbeda-beda. Studi lain menunjukkan bahwa mengganti diet Jurnal Gizi Unimus Vol 10 No 12021
$1 \%$ lemak tersaturasi dengan $1 \%$ karbohidrat dapat meningkat kadar trigliserid $1 \mathrm{mg} / \mathrm{dl}$ yang akan berdampak pada peningkatan kadar kolesterol total.(John, 2006 ; Zha S, et al. 2005) Hasil penelitian yang dilakukan pada 14 wanita sehat postmenopausal dan mendapatkan peningkatan asupan makanan menyebabkan peningkatan kadar trigliserida, tetapi tidak didapatkan dari hubungan antara asupan karbohidrat dengan kadar kolesterol. ( Snacks, et al. 2017) Hasil penelitian ini menunjukkan adanya penurunan kadar trigliserida pada kelompok intervensi yang diduga disebabkan karena pemberian formula mengandung isoflavon, tocopherol dan serat. Beberapa penelitian menunjukkan bahwa asupan kedelai dapat menurunkan absorbsi langsung kolesterol di usus, sehingga kadar kolesterol ester menurun. Hal ini pula mengakibatkan penurunan kadar kolesterol total dalam darah.(Miriam LA, et al. 2001)

Pemberian isovlavon dalam tempe dan $\alpha$-tocopherol dalam bekatul apabila diberikan secara bersama dalam bentuk formula hasilnya jauh lebih baik dibandingkan dengan diberikan hanya tempe atau tepung tempe serta bekatul saja dalam menurunkan kadar kolesterol.

Hasil penelitian pemberian Petulpada wanita menopause dengan dislipidemia terbukti signifikan dalam menurunkan IMT dan kadar kolesterol total.

\section{KESIMPULAN DAN SARAN}

\section{Kesimpulan}

Pemberian formula Petulsebanyak 37,33 gr/kali 
minum sebanyak $3 \mathrm{X} / \mathrm{hr}$ selama 21 hari dapat memperbaiki status gizi berdasarkan IMT dan dapat menurunkan kadar kolesterol total..

\section{Saran}

Perlu dilakukan penelitian lanjutan pengaruh pemberian formula tepung tempe dan bekatul terhadap kadar gula darah pada wanita menopause dislipidemia.

\section{Ucapan terima Kasih}

Ucapan terima kasih kepada : Rektor Unimus, atas dukungan dana dan fasilitas pada penelitian ini. Penelitian ini telah memperoleh ijin etik dari Komisi Etik, Fakultas Kedokteran Universitas Diponegoro Semarang No. 455 / EC/FK-RSDK/VII/2019.

\section{DAFTAR PUSTAKA}

Adam, John M.F. 2006. Dislipidemia. Dalam: A.W. Sudoyo, B. Setiyodadi, I. Alwi, M. Simadibrata, S. Setiati, ed: Buku Ajar Ilmu Penyakit Dalam. Edisi ke-4. Jilid III. Jakarta: FK-UI. Hal 1926-1932

Anderson JW, Johnstone BM, Cook-Newell ME. Meta-Analysis of the Effects of Soy Protein Intake on Serum Lipids. N Engl J Med. 2005;333(5):276-82

Arianti R, Rizatania V, Fasitasari M, Sarosa H. Perbedaan Efektifitas Bekatul, Tepung Tempe dan Angkak dalam Menurunkan Kadar Kolesterol Total Darah. Sains Med. 2009 ;1(1):63-70

Arjatmo, T. dan Utama, H., 2004, Buku Ajar Ilmu Penyakit Dalam Jilid I, Edisi 3,Balai Penerbit FKUI, Jakarta

Astuti M, Meliala A, Dalais FS, Wahlqvist ML. Tempe, a nutritious and healthy food from Indonesia. Asia Pac J Clin Nutr. 2000;9(4):322-325

Astuti S. Isoflavon kedelai dan potensinya sebagai penangkap radikal bebas. J Teknol Dan Ind Has Pertan. 2012;13(2):126-36.
Badan Perencanaan Pembangunan Nasional Badan Pusat Statistik. Proyeksi penduduk Indonesia 2010-2035. Jakarta: Badan Pusat Statistik, Jakarta-Indonesia. 2013:32-5.

Baker VL, Leitman D, Jaffe RB. 2000. Selective estrogen receptor modulators inreproductive medicine and biology. Obstet Gynecol Surv 55(suppl 2):S21S4

Borden L. Your Menopause Handbook - A Self-Help Guide for Healthy Living A Woman's Self-Help Guide to Menopause Management. Lulu Press, Inc. 2013:p73

CarrolMD,BrianK, DavidAL. Total and high density lipoprotein in cholesterol in adults: National Health and Nutrition Examination Survey,2009-2010. NCHS Data Brief.no92. April2012

Cena ER, Steinberg FM. Soy may help protect against cardiovascular disease. Calif Agric. 2011;65(3):118-23.

Charles R Elder, MDChristina M Gullion, Kristine L Funk, MSLynn L DeBar, Nangel M Lindberg, , and Victor J Stevens, . Impact Of Sleep, Screen Time, depression and Stress On Weight Change In The Intensive Weight Loss Phase Of The Life Study. Int J Obes (Lond). 2012: ; 36(1): 86-9

Clair RS, Anthony M. Soy, isoflavones and atherosclerosis. Handb Exp Pharmacol. 2005;(170):301-23

Departemen Kesehatan RI. 2004. Survei Kesehatan Rumah Tangga (SKRT) 2004. Badan Penelitian dan Pengembangan Kesehatan: Jakarta

Erwinanto, Santoso,A, Putranto.J.N.E, Tedjasukmana,P, Suryawan,R, Rif,S. Pedoman Tatalaksana Dislipidemia. 1st ed. Centra Communications. 2013;1:536

Goodman dan Gilman, 2008, Dasar Farmakologi Terapi, diterjemahkan oleh Tim Alih Bahasa Sekolah Farmasi ITB, Volume 1, Penerbit BukuKedokteran EGC, Jakarta

Gropper SS, Jack L Smith, James L. Groff. 2005. Advanced nutrition and humanmetabolism, fourth edition. Thomson Wadsworth 
Gruber, Cristian J, 2002, Production and Action ofEstrogen, The New England Journal ofMedicine, vol. 346, viewed: 3 juni

2010(http://www.nejm.org/cgi/reprint/ 346/5/340

Hirano T, Ito Y, Koba S, Toyoda M, Ikejiri A, Saegusa H, et al. Clinical significance of small dense low-density lipoprotein cholesterol levels determined by the simple precipitation method. Arteriosclerosis, thrombosis, and vascular biology. 2004;24:558-563

Hernawati, Manalu W., Suprayogi A., dan Astuti D.A. 2013. Perbaikan Parameter Lipid Darah Mencit Hiperkolesterolemia dengan Suplemen Pangan Bekatul. Majalah Kedokteran Bandung. Vol. 45(1) : 1-9.

Hegsted M, Windhauser MM, Morris SK, Lester SB. Stabilized rice bran and oat bran lower cholesterol in humans. Nutr Res. 2003;13(4):387-98

Ilsakova L, Riecanskỳ I, Jagla F. The physiological actions of isoflavone phytoestrogens. Physiol Res. 2010;59(5):651

Kementrian Kesehatan Republik Indonesia. Profil Kesehatan Indonesia. Jakarta: .2013: 162-189

Labarthe, D.R. 2011. Epidemiology and

Prevention of Cardiovascular Diseases : A

Global Challenge - 2nd Ed. Sudbury,

Massachusetts, US: Jones and Bartlett

Publishers, LLC.

Luh BS, Barber S, Barber CB de. Rice Bran: Chemistry and Technology. In: Rice. Springer, Boston, MA; 2000. p. 732-81.

Miriam LA, de Kleijn JJ, van der Schouw YT, Wilson PWF, Adlercreutz H, Mazur $\mathrm{W}$, et al. Intakeof dietary phytoestrogens is low in postmenopausalwomen in the United States: The Framinghamstudy. J. Nutr 2001; 131: 1826-32

Nout MJR, Kiers Jl., 2005. Tempe Fermentation, innovation, and functionality: update into the third millennium. App Environ Microbiol 98:789--805
Packett L V., Chen LH, Liu JY. (2001). Antioxidant Potential of Tempeh as Compared to Tocopherol. Journal of Food Science, 36:798-799

Ricciarelli R, Zingg J-M, Azzi A. Vitamin E reduces the uptake of oxidized LDL by inhibiting CD36 scavenger receptor expression in cultured aortic smooth muscle cells. Circulation. 2000;102(1):82-87.

Riset Kesehatan Dasar [RISKESDAS]. 2013. Jakarta: Badan Penelitian danPengembangan Kesehatan, Departemen Kesehatan, Republik Indonesia

Roger, et,al. (2011). Heart Disease and Stroke Statistic 2011 Update: A Report from the American Heart Assosiation. Diakses tanggal 10 Agustus 2016 dari http://circ.ahajournals.org/context/early/ 2011/12/15/12/ciroboI3e31823ac046.DC.I

Sacks FM, Lichtenstein AH, WU JHY, Appel LJ, Creager MA, Etherton PM, et al. Dietary fats and cardiovascular disease: a presidential advisory from the american heart association. Circulation. 2017; 135:00

Sihadi. 2006. Sport and Nutrition. Jurnal Kedokteran yarsi, 14 (1) : 078-084

Sharif MK, Butt MS, Anjum FM, Khan SH. Rice Bran: A Novel Functional Ingredient. Crit Rev Food Sci Nutr. $2014 ; 54(6): 807-16$.

Soegondo S, at al 2009. Obesitas balai penerbit fakultas kedokteran universitas indonesia, jakarta. Dalam ilmu penyakit dalam universitas ind

Sugiri. High refined carbohydrate intake play role as important coronary artery disease risk factor.How can it be? Unpublished.Asmiha.2013

Sussi Astuti. Soybean Isoflavone and Its Potentially as Scavenger Free Radicals. Teknol Ind Dan Has Pertan. 2008 ;13(2):126-36

Taku K, Keizo Umegaki, Yoko Sato, Yuko Taki, Kaori Endoh and ShawWatanabe (2007). Soy isoflavones lower serum total and LDL cholesterolin humans: a meta-analysis of 11 randomized 
controlled trials. Am J ClinNutr 85:1148-56

Tee ES, Khor GL, Ng TKW, Zaitun Y, Chee HL, Safiah MY. Nutritional assessment of rural villages and estates in Peninsu lar Malaysia. III. Prevalence of anemia. Malaysian J Nutr. 2002;4:1-30

Tim Riset Kesehatan Dasar. Pedoman Pengambilan,Penyimpanan,

Pengemasan dan Pengiriman Spesimen Darah. Badan Penelitian dan pengembangan Kesehatan Departemen Kesehatan RI; 2007.p1-14.

Utaminingsih, RW. 2009.Mengenal dan Mencegah Penyakit Diabetes, Hipertensi,Jantung dan Stroke untuk Hidup Lebih Berkualitas. Media Ilmu. Yogyakarta

Utari,D.M. Efek Intervensi Tempe terhadap Profil Lipid, Superoksida Dismutase, LDL Teroksidasi dan Malondialdehyde Pada Wanita Menopause. Inst Pertan Bogor. 2011;11-8

Van Bennekum,A.M, V.Nguyen,D

Schulthess, G, Hauser,H, C.Philips. Mechanisms of cholesterol-lowering effects of dietary insoluble fibres: relationships with intestinal and hepatic cholesterol parameters. $\mathrm{Br} \mathrm{J}$ Nutr. 2005;331-7

Wilson RB, Middleton CC, Sun GY. Vitamin E, Antioxidants and Lipid Peroxidation in Experimental Atherosclerosis of Rabbits. J Nutr. 2008;108(11):1858-67

Wirawanti,I.W, Hardinsyah, Briawan,D, Astawan,M. Efek Intervensi Minuman Tempe Terhadap Penurunan Kadar Low Density Lipoprotein. J Gizi Pangan. 2017;12(1):9-16

World Health Organization, 2008. Centralized Pan Asian Survey on the Undertreatment of Hypercolesterolemia. Diunduh 24 Oktober 2011, http://who.int/research/en.

Yi KW, Shin J-H, Seo HS, Lee JK, Oh M-J, Kim T, et al. Role of Estrogen Receptor- $\alpha$ and $-\beta$ in Regulating Leptin Expression in 3T3-L1 Adipocytes. Obesity. $2008 ; 16$ (11) : 2393-9.

Zaidi SMKR, Banu N. Antioxidant potential of vitamins $\mathrm{A}, \mathrm{E}$ and $\mathrm{C}$ in modulating oxidative stress in rat brain. Clin Chim Acta. 2004;340(1-2):229-33.

Zakaria FR, DN Faridah, Sandjaja, \& Pramudya SM. 2000. Hubungan antara status imunologi dan pola konsumsi makanan jajanan populasi remaja di Bogor Jawa Barat. Jurnal Teknologi dan Industri Pangan, 1(2), 50-59

Zhan S, Ho S. Meta-analysis of the effects of soy protein containing isoflavones on the lipid profile. Am J Clin Nutr 2005; 81: 397-408 